\section{Response to: 'Serum complement factor C5a in IgG4-related disease' by Fukui et al}

We appreciate the interest shown by Dr S Fukui and colleagues ${ }^{1}$ in our recent paper, 'How to diagnose IgG4-related disease (IgG4-RD)'. ${ }^{2}$

IgG4-RD is characterised by increased serum IgG4 concentrations and number of IgG4-positive plasma cells in affected lesions. ${ }^{3}$ However, its diagnosis can be difficult, because clinical signs vary depending on the organs affected.

A Japanese team established comprehensive diagnostic criteria for IgG4-RD, 2011 focusing on the concentration of serum IgG4 (>135 mg/dL), numbers of IgG4-positive cells (>10 cells/ $\mathrm{HPF})$ and ratio of IgG4-positive to IgG-positive cells $(>40 \%)$ in affected tissues. ${ }^{4}$

However, many cases of IgG4-RD with low levels of IgG4 and mimickers of IgG4-RD with increased serum IgG4 have been reported and the concept of IgG4-RD has become blurred. Therefore, new specific markers or new criteria for IgG4-RD are required. ${ }^{5}$

Human IgG4 has a unique structure distinguished from the other IgG subclasses by lack of interaction with the complement system and inability to activate the classical complement pathway. ${ }^{67}$ However, hypocomplementaemia has been observed in IgG4-RD ever since the concept was first established ${ }^{8}$ and is in particular more frequent and sometimes severe in IgG4-related kidney disease. ${ }^{9}$ A recent study showed that non-IgG4 IgG such as IgG1, which can activate complement, might be involved in the activation of complement in IgG4-RD. ${ }^{10}$

Fukui et al reported the significant increase of C5a in IgG4-RD and suggested it for a therapeutic target. ${ }^{1}$ However, serum C5a elevation is also a very important feature of active systemic lupus erythematosus (SLE). Since elevated C5a levels in IgG4-RD are much lower than in active lupus cases ${ }^{11}$ and only some groups of patients with IgG4-RD have hypocomplementaemia, the production of C5a in SLE and IgG4-RD likely exhibits significant differences in both underlying mechanism and pathogenetic role.

Although the details of the pathogenesis of IgG4-RD are unclear at present, recent basic studies have implicated the tolllike receptor (TLR) signalling pathway. ${ }^{12}$ Activation of C5aR in macrophages inhibits TLR-4 signals resulting in reduction of IL-12, IL-23 and IL-27 production by inflammatory macrophages. ${ }^{13}$ Thus, the role of cross-talk between innate and acquired immunity through the complement pathway and TLR system is attracting attention in the pathogenesis of IgG4-RD. ${ }^{14}$

\section{Hisanori Umehara, ${ }^{1}$ Mitsuhiro Kawano ${ }^{2}$}

'Division of RA and Autoimmune Diseases, Nagahama City Hospital, Shiga, Japan ${ }^{2}$ Division of Rheumatology, Department of Internal Medicine, Graduate School of Medical Science, Kanazawa University, Ishikawa, Japan
Correspondence to Professor Hisanori Umehara, Division of RA and Autoimmune Diseases, Nagahama City Hospital, Shiga 526-8580, Japan; umehara606@gmail.com Handling editor Josef S Smolen

Competing interests None declared.

Patient consent Not required.

Provenance and peer review Commissioned; internally peer reviewed.

(c) Article author(s) (or their employer(s) unless otherwise stated in the text of the article) 2019. All rights reserved. No commercial use is permitted unless otherwise expressly granted.

\section{Check for updates}

To cite Umehara H, Kawano M. Ann Rheum Dis 2019;78:e66.

Received 17 May 2018

Accepted 17 May 2018

Published Online First 6 June 2018

\section{S Linked}

- http://dx.doi.org/10.1136/annrheumdis-2018-213705

Ann Rheum Dis 2019;78:e66. doi:10.1136/annrheumdis-2018-213729

\section{REFERENCES}

1 Fukui S, Fujita Y, Origuchi T, et al. Serum complement factor C5a in Ig $\mathrm{G}_{4}$-related disease. Ann Rheum Dis 2018;78:e65.

2 Umehara H, Okazaki K, Kawano M, et al. How to diagnose IgG4-related disease. Ann Rheum Dis 2017;76:e46.

3 Umehara H, Okazaki K, Masaki Y, et al. A novel clinical entity, IgG4-related disease (IgG4RD): general concept and details. Mod Rheumatol 2012;22:1-14.

4 Umehara H, Okazaki K, Masaki Y, et al. Comprehensive diagnostic criteria for lgG4related disease (IgG4-RD), 2011. Mod Rheumatol 2012;22:21-30.

5 Umehara H, Okazaki K, Nakamura T, et al. Current approach to the diagnosis of IgG4-related disease - Combination of comprehensive diagnostic and organ-specific criteria. Mod Rheumatol 2017;27:381-91.

6 Schuurman J, Perdok GJ, Gorter AD, et al. The inter-heavy chain disulfide bonds of IgG4 are in equilibrium with intra-chain disulfide bonds. Mol Immunol 2001;38:1-8.

7 van der Neut Kolfschoten M, Schuurman J, Losen M, et al. Anti-inflammatory activity of human IgG4 antibodies by dynamic Fab arm exchange. Science 2007;317:1554-7.

8 Masaki Y, Dong L, Kurose N, et al. Proposal for a new clinical entity, IgG4-positive multiorgan lymphoproliferative syndrome: analysis of 64 cases of lgG4-related disorders. Ann Rheum Dis 2009;68:1310-5.

9 Kawano M, Saeki T, Nakashima H, et al. Proposal for diagnostic criteria for lgG4related kidney disease. Clin Exp Nephrol 2011;15:615-26.

10 Yamada K, Yamamoto M, Saeki T, et al. New clues to the nature of immunoglobulin G4-related disease: a retrospective Japanese multicenter study of baseline clinical features of 334 cases. Arthritis Res Ther 2017;19:262.

11 Sakuma Y, Nagai T, Yoshio T, et al. Differential activation mechanisms of serum C5a in lupus nephritis and neuropsychiatric systemic lupus erythematosus. Mod Rheumatol 2017;27:292-7.

12 Watanabe T, Yamashita K, Sakurai T, et al. Toll-like receptor activation in basophils contributes to the development of IgG4-related disease. J Gastroenterol 2013:48:247-53.

13 Hawlisch H, Belkaid Y, Baelder R, et al. C5a negatively regulates toll-like receptor 4-induced immune responses. Immunity 2005;22:415-26.

14 Umehara H, Nakajima A, Nakamura T, et al. IgG4-related disease and its pathogenesis-cross-talk between innate and acquired immunity. Int Immunol 2014;26:585-95. 